DEBORAH JENSON

\title{
The Persons and Things School: Parrots, Peasants, and Pariahs in "Un Coeur simple" and La Chaumière indienne
}

Barbara Johnson's critical work on the figure of difference is well known, but her extensive teaching and writing on the theme of "persons and things" is less recognized. The MLA International Bibliography yields only six "persons and things" titles, one of them for a Harvard dissertation abstract, but the great majority of former students and academic peers who have been influenced by the rubric and brought its epistemological insights to their own critical methodology have not re-used the expression, viewing it, perhaps, as “copyrighted” by Johnson. Yet Johnson's primary use of the "persons and things" in a sustained pedagogical project encouraged its association with method and mimesis rather than with one scholar's “ideas," despite its unstated prominence in her own work in essays such as "Using People," "Apostrophe, Animation, and Abortion," and “Ode on a Public Thing." As I write this article in 20o6, her book manuscript Persons and Things is in the publication pipeline. Its appearance in print will no doubt further help to launch a minor critical "school."

I have put quotation marks around "school" to indicate its double valence in this essay. The critical usefulness of "persons and things"

Volume 17, Number 3 DoI 10.1215/10407391-2006-014

(ㄱ) 2006 by Brown University and $\mathrm{d}$ i f f e $\mathrm{r}$ e $\mathrm{n}$ c e $s$ : A Journal of Feminist Cultural Studies 
draws on the inherent didactic potential of thinghood to reveal threats to, limitations of, and hybridity within personhood. As Alain Pottage notes, "There is a resonance between emergent social anxieties and the recent questioning of the distinction between persons and things" (5n10). As Johnson has taught it, the juncture of person and thing is itself a "school" in which similitude and difference are taught unconventionally-mutely, by the unschooled, sometimes by the inanimate. ${ }^{1}$ In this article, I read the overlap between person and thing status as a question of caste politics in the intertextuality that binds Gustave Flaubert's "Un Coeur simple" ("A Simple Heart") (1876) with Jacques Henri Bernardin de Saint-Pierre's La Chaumière indienne (The Indian Hut) (1790). These two texts, which employ the trope of "parroting" in their questioning of the difference between the peasant, the pariah, and the nonhuman, thematize the education of (and by) the abject in a manner that illuminates the interest of the persons and things school.

As an expression, "persons and things" is often found in linguistic science (e.g., Pontes's "The Distinction between Persons and Things in Portuguese Pronouns"), but its origins lie in the discourse of law. Pottage summarizes:

The distinction between persons and things has always been central to legal institutions and procedures. The institutions of Roman law, to the extent that Rome can be taken as the origin of the Western legal tradition, attached persons (personae) to things (res) by means of a set of legal forms and transactions (actiones) which prescribed all of their permissible combinations. (4)

The juridical language of persons and things has found its way into every nook and cranny of Western culture, from political science (the res publica or "republic") to fiction (think of Charles Dickens's chapter title "Persons and Things in General" in Our Mutual Friend).

The slave, who is generally but not always, as we will see in La Chaumière indienne, at the bottom of class or caste systems, is a particularly bitter paradox of simultaneous person and thing status. Slavery, as well as forced prostitution, represents a clear transgression of the person/thing distinction. But this binary relation of person and thing (ostensibly analogous to the distinction between free person and slave) is also increasingly undermined by recent developments in science and technology. Pottage writes, 
Although the theme of slavery still informs critiques of contemporary technology (it is often asked, for example, how the "ownership" of genes or embryos is different from the ownership of slaves) the real problem is that we can no longer divide the world into the two registers that are presupposed by any argument against slavery. Now, the problem is that humans are neither person nor thing, simultaneously person and thing, so that law quite literally makes the difference. (5)

Like slavery, postmodern technology problematizes the difference between person and thing in domains ranging from robotics to biotechnology patents to stem cell research. Today, the class of owners themselves (the former "masters") may seek out self-objectification through plastic surgery, becoming more "artificial" and thingified in the pursuit of enhanced personification. Such omnipresent technological blurrings of person/thing distinctions in the contemporary world also raise the question of whether the ideal construct of the person, uncontaminated by thinghood-the person as the purely human binary opposite of the slave as pure property-has ever been realistic. Similarly, current research on the complexity and variety of the social existences of slaves tends to destabilize absolute associations of historical enslavement with reification. The dynamic historical record of manifested personhood on the part of slaves, including the strategic and ideological nature of slaves' responses to their legal and social thingification, serves as a corrective to overly literalist understandings of the antislavery argument that slaves were "deprived of their humanity." Johnson's "persons and things" work has similarly avoided static binarisms of person and thing, just as her work on difference has deconstructed other binarisms. This means, in brief, that the political import of her persons and things work does not rely heavily on the pathos of the thingified person. It focuses, rather, on differences generated and organized by the person/thing distinction, especially on rhetorical play with the political and subjective stakes of cultural animation and inanimation.

In "Ode on a Public Thing," Johnson looks at the ways Robert Lowell's poem "For the Union Dead" is-and is not-about "the black soldiers who enlisted in Colonel Robert Gould Shaw's 54, th Massachusetts Regiment [and who] were as heroic and self-sacrificing as their leader" (Johnson, "Ode" 137). She in effect imitates the "fishy" symbolic logic of Lowell's poem, in which repeated aquatic symbolism intervenes to make 
the poetic referent of American race relations neither fish nor fowl, a problem trapped in a bubble, behind the glass of an aquarium wall or a television screen flashing images of civil rights protesters. Rather than serving as a monument to the valor of former slaves fighting for the Union, the poem comes to serve as "a good thick description of ambivalence toward monumentality" (14,1). Johnson's essay likewise interweaves oblique references to the poem's allusions to race, slavery, "Niggers," civil rights, and "Negroes" into her more detailed evocation of "the astonishingly disparate collection of things" in the poem in order to represent performatively the ways the black soldiers "remain trapped in the plane of representation in this poem," like fish in an aquarium, or like fish out of water (137). The gap in American historical consciousness where African American civil and military action should be is the space of a nonmonument; rather than a lieu de mémoire or memory site, to borrow Pierre Nora's terminology, black military engagement in conflicts fundamental to national history is recognized by a nonplace, a detour, the opposite of a commonplace acknowledgement. Johnson puts what might have been the conclusion to her essay squarely in the middle of the text, reiterating the overlooking and sidestepping of the monument. For the epigraph to his poem, Lowell had reused a Latin motto that would normally translate as "He leaves all else to serve the republic"-but he transcribes it in a slightly altered form, opening an oblique space of difference. Johnson further departs from the original by considering the resonance of an altered rendition of the epigraph, in which the black soldiers serve the public thing while also serving as public things: "They [the black soldiers] leave all else to serve (as) a public thing" (138).

In Flaubert's "Un Coeur simple," the reader is invited to question the individuation and humanity of the main character, Félicité, a peasant who becomes a servant. ${ }^{2}$ But gradually, the tables are turned in the story, as Félicité proceeds to question, and even overturn, hierarchies and distinctions of person and thing.

As the perfect servant and therefore the envy of the bourgeois community of Pont-l'Evêque, Félicité has the allure of an automaton: "[E]lle [...] semblait une femme en bois, fonctionnant d'une manière automatique" (4.5). [She seemed like a woman made of wood, functioning automatically. $]^{3}$ Her thing-like status is compounded by passages in which her identity seems to fuse with or fade in and out of that of her 
employer. On the opening page of the story, Flaubert makes it difficult to distinguish grammatically between the subject status of Félicité and that of her mistress, Mme Aubain, by alternating between descriptions of the two women, each of whom is designated only by the pronoun "she." The first paragraph presents Mme Aubain as subject, but in the second paragraph, the subject pronoun "she" refers to Félicité, identified only by her domestic functions:

Pour cent francs par an, elle faisait la cuisine et le ménage, cousait, lavait, repassait, savait brider un cheval, engraisser les volailles, battre le beurre, et resta fidèle à sa maîtresse-qui cependant n'était pas une personne agréable. (43)

[For one hundred francs a year, she did the cooking and cleaning, the sewing, washing, and ironing; she knew how to bridle a horse, fatten poultry, churn butter, and throughout, she remained faithful to her mistress, who was not a particularly nice person.]

In the subsequent paragraph, which begins "Elle avait épousé un beau garcon sans fortune" [She had married a handsome young man with no fortune of his own], the subject pronoun "she" refers not to Félicité but to Mme Aubain. This passing off of the baton of subjecthood from mistress to servant and back again inaugurates the problem of Félicité's autonomy and equality. Flaubert's famously neutral omniscient narration is not above signaling problems of status through structures of address as well as through symbolism and repetition.

The near confusion of Mme Aubain and Félicité in the beginning of the story can be read not just as an interrogation of Félicités autonomy and equality but, conversely, as a refusal to support on the level of narrative framing the master/servant segregation structured into Mme Aubain's bourgeois social world. The subject pronoun "elle" in the fourth paragraph of the story, which clearly refers back literally to the feminine noun "house," also symbolizes the stumbling of characters (and readers) over uneven hierarchical levels in the household: "Elle avait intérieurement des différences de niveau qui faisait trébucher" (43). [Inside there were differences of level which caused people to stumble.]

Félicité's social inequality is anchored in her lack of formal schooling, but the text presents a detailed record of the informal schooling she has acquired. Before being hired as a servant to Mme Aubain, Félicité had been taken in and raised on a farm after the death of her father, a 
mason, in a fall from some scaffolding. The description of her early education focuses primarily on what she had learned from farm animals: "Elle n'était pas innocente à la manière des demoiselles,-les animaux l'avaient instruite" (46). [She wasn't naive in the manner of young ladies, for she had learned a great deal from animals.] This knowledge is later supplemented by her "literary education" (éducation littéraire [49]), consisting of one of her young charges' explanations of illustrations in his geography textbook. These scenes of sensationalistic ethnographic otherness include "des anthropophages coiffés de plumes, un singe enlevant une demoiselle, des Bédouins dans le désert, une baleine qu'on harponnait, etc." (4,8) [cannibals in feather headdresses, a monkey carrying off a young lady, Bedouins in the desert, a whale being harpooned, etc.]. Félicité also receives second-hand religious instruction when she accompanies Mme Aubain's daughter, little Virginie, to her catechism lessons. Although Félicité understands nothing of dogma, and "ne tâcha même pas de comprendre" (55) [did not even try to understand], she engages vividly with the iconic images in the stained glass windows and with the high points of biblical history as summarized by the priest; her "religious education" (éducation religieuse [55]) is verbal and visual. Her education is also imitative: after observing Virginie's preparations for her first communion, "elle imita toutes les pratiques de Virginie" (55) [she imitated everything Virginie did], attaining an almost mystical union with her little mistress, verging on an interpersonal version of the spiritual ideal of "the imitation of Christ."

Félicité's “wooden” demeanor, her acceptance of her subaltern status, and her unschooled perceptions of the world traditionally have prompted many readers to assume that the story is ironic at her expense, that the narration in effect "agrees" with the pompous and corrupt lawyer, Bourais, who erupts into sneezes and laughter when she misuses a world map, “tant son intelligence était bornée!" (6o) [so limited was her intelligence!]. But as Naomi Schor notes, "Flaubert defended his text against the ironical reading. 'This is not at all ironical as you may suppose,' Flaubert wrote [. . .]. 'I want to move tender hearts to pity and tears, for I am tenderhearted myself'" (Schor 769-70). The poles of irony and pathos have organized a great deal of critical debate on "Un Coeur simple" and distracted critical attention from the possibility that Flaubert might also evoke otherness, but in the terms in which someone like Félicité is socially othered: that he was making the subaltern speak without translating from the discourse of her abjection. Félicité, in this reading, would be less 
"ironic" as a character if her creativity and individuality were represented and defended in the terms of bourgeois abstractions, in the conventions of Western humanistic and religious education and print culture. Félicité, however, works with the conventions of the material culture in which her role is defined by servility. She "thinks with things," as I have argued at greater length elsewhere (see Jenson). "Un Coeur simple" is arguably neither "ironic" at Félicité's expense nor particularly "tenderhearted"; it presents her not so much as an object of pathos as an inventive subject in the world of differences-and similarities-between persons and things.

The main "thing" around which Félicité constructs a system of meaning in the story is not a thing but not a person either: it is a parrot. Parrots represent a distinctively human capacity, speech, emptied of its humanness. The bird, named "Loulou," appears at first to represent this evacuated linguistic dimension. Loulou's speech is limited to the most servile verbal formulas: Félicité teaches him to say "Charmant garçon! Serviteur, monsieur! Je vous salue, Marie!” (68). [Charming boy! Your servant, Sir! Hail Mary!] Those who enter the house are astonished to learn the bird's name is not "Jacquot," "puisque tous les perroquets s'appellent Jacquot" (68) [because all parrots are named Jacquot]. But just as Loulou's three phrases represent submission so thoroughly that they become symbolic of the dynamics of submission itself, the name "Jacquot" has unmistakable associations with the peasant class in France. Beginning with a peasant rebellion led by the incongruously named "Jacques Bonhomme" in 1358, not only were peasant rebellions known as "jacqueries" but peasants acquired the generic sobriquet of "Jacques" or "Jacquot" ("Jacquerie"). Furthermore, Loulou is compared by others "à une dinde, à une bûche" (68) [to a turkey, a block of wood]. The townspeople's expectation that he will have an entirely generic name representing not only his status as parrot but the lack of cultural individuation of the peasant class creates a pointed analogy between the bird and Félicité. Loulou's characterization provides a metadiscourse on the "parroting class," compelled by social status to limit speech acts to signs of servility. Félicité as a "woman made of wood" and Loulou as a "block of wood" are two of a kind: animate beings overlapping socially with things.

It is easy to overlook the fact that the figure of the parrot in "Un Coeur simple" is presented in tandem with the figure of the slave. The parrot first arrives in Pont-L'Evêque in the wake of the populist revolution of July 1830, when a new subprefect is installed in relation to the change in the political system. He is the Baron de Larsonnière, a former 
consul from "America" (65), probably the French Caribbean colonies. ${ }^{4}$ The subprefect's household includes his sister-in-law's three daughters, who "possédaient un nègre et un perroquet" (65) [possessed a negro and a parrot]. The household presumably possessed a good deal more than that, but by mentioning only the negro and the parrot, these two talking "things" are marked as singularly possessed. The mention of the negro, who on a legal level would have been defined as a servant once in France, ${ }^{5}$ also recalls the fact that Félicité's one suitor as a young girl had abandoned her in order to marry a wealthy older woman who could save him from the military draft; the previous year his parents "avaient acheté un homme" $(46)$ [had bought a man] to replace him for military service, but Théodore feared he might still be called up. A network of the not-quite-free begins to crystallize in the story around the servant, the "negro," the bought man, and the parrot. The vague apprehension of slavery in the narrative is further sketched through the death of Félicité's beloved nephew, Victor, in Havana. Prior to his death, Félicité imagines that "Victor circulait parmi des nègres dans un nuage de tabac" (6o) [Victor circulated among the negroes in a cloud of smoke].

When de Larsonnière is promoted to the prefecture, "Mme de Larsonnière's negro" (le nègre de Mme de Larsonnière [67]) brings the parrot as a gift to Mme Aubain. This gesture follows a conversation in which Félicité had confided to the black man that the parrot reminded her of her nephew because it came from America and that her mistress would love to have it; he had passed the latter comment on to his mistress when the time came to move. This small chain of events reveals an element of complicity between Félicité and the former slave, as well as Félicité's attraction to the parrot as an emblem of the colonies. The subject of colonial slavery, with its fundamental tensions of person and thing, hovers in the background of this story about servility in the metropole.

As in the case of Félicité, Loulou's limitations are partly a failure of imagination on the part of those who presume those limitations to be absolute, an ironic commentary on those who take "inferior" class status literally. Loulou in fact demonstrates a considerable degree of social initiative and insight. In an obstinate act of passive aggression, he refuses to speak when others try to draw him into dialogue, although he appreciates company and carries on with deafening vivacity during card games. Most significantly, Bourais, who had taken such mirthful pleasure in Félicité's limitations, now finds himself the target of Loulou's carnavalesque laughter: 
La figure de Bourais, sans doute, lui paraissait très drôle. Dès qu'il l'apercevait, il commençait à rire, à rire de toutes ses forces. Les éclats de sa voix bondissaient dans la cour, l'écho les répétait, les voisins se mettaient à leurs fenêtres, riaient aussi. (68) [Bourais's face apparently struck him as terribly funny. As soon as he caught sight of him, he began to laugh, to laugh with all his might. His outbursts resounded in the courtyard, the echo repeated them; neighbors came to their windows and began to laugh too.]

The irony in this scene is not at the expense of the allegedly dim-witted bird.

Over time, the resemblance between Félicité and the bird is further accentuated. Subsequent to an ear infection that severely damages her hearing, “elle parlait très haut, même à l'église” (69) [she spoke very loudly, even at church]. Her mistress makes a refrain of the comment "comme vous êtes bête!" (70) [how stupid you are!]. The adjective "bête," "stupid," brings to mind the noun "bête," meaning "animal," "creature," or "pet”: Félicité and Loulou are each in their own way "bête." Increasingly isolated in a world in which other people seem to circulate "avec le silence des fantômes" (70) [in ghostly silence], Félicité can now hear only the voice of Loulou. The bird becomes "presque un fils, un amoureux" (70) [almost a son, a lover]. Although their verbal interactions remain limited on Loulou's part to the three phrases of his repertory, ${ }^{6}$ in the context of their dialogue, they represent a complete semiotic system of intimate communication: "Ils avaient des dialogues, lui, débitant à satiété les trois phrases de son répertoire, et elle, y répondant par des mots sans plus de suite, mais où son coeur s'épanchait" (70). [They had dialogues in which he repeated the three phrases of his repertory endlessly and she responded by pouring her heart into similarly randomly chosen words.]

When Loulou dies, Félicité has his cadaver stuffed. She puts the stuffed parrot in her attic bedroom, which is now characterized by an eclectic profusion of things: "Cet endroit [. . .] avait l'air tout à la fois d'une chapelle et d'un bazar, tant il contenait d'objets religieux et de choses hétéroclites" (72). [The place was so cluttered with religious objects and miscellaneous things that it seemed like a cross between a chapel and a general store.] Mme Aubain dies, and Félicité grieves for this haughty woman "comme on ne pleure pas les maîtres" (74) [with a grief one does not feel for masters]. Living on alone for years on a tiny legacy from Mme 
Aubain in the house that fails to sell, her own thing-like status is increasingly evident: "[E]lle vivait dans une torpeur de somnambule” (73). [She lived in a state of torpor, like a sleepwalker.]

Throughout her long decline, Félicité is absorbed by a resemblance between Loulou, set on the edge of a chimney in her attic room, and a representation in a stained glass window at church of the Holy Spirit hovering over the Virgin (or towering over the Virgin; the verb used is "dominer," so there are connotations of authoritarian dominance). She then compares this window with a representation of the Holy Spirit in a popular image of the baptism of Christ. ${ }^{7}$ In Félicité's view, it is the Holy Spirit who resembles Loulou, rather than the other way around. She buys a copy of the popular print and hangs it next to Loulou, so that she can see them side by side. Soon, the Holy Spirit and Loulou become inseparably linked in her imagination. In what amounts to a private cult of her own invention, Loulou is sacralized, and the mystery of the trinity and icon of the Holy Spirit become "intelligible," readable: "Ils s'associèrent dans sa pensée, le perroquet se trouvant sanctifié par ce rapport avec le Saint Esprit, qui devenait plus vivant à ses yeux et intelligible" (73). [Once she had made this association, the parrot was sanctified by this relation to the Holy Spirit, and the Holy Spirit in turn became more real and intelligible.] She hypothesizes that God would not have chosen a dove to announce his presence, "puisque ces bêtes-là n'ont pas de voix" (73) [because those creatures have no voice], but rather, a parrot, an ancestor of Loulou. Félicité develops "l'habitude idolâtre" (74) [the idolatrous habit] of saying prayers to the Holy Spirit while kneeling before Loulou.

In her final spring, when she is afflicted with pneumonia, the parish decides to put one of the altars for the Corpus Christi procession in the courtyard in front of Mme Aubain's house. Félicité wants to contribute her most precious object to it: Loulou. As the procession pauses at the altar below her garret, her last moments of consciousness unfold. In this final scene, two verbs that had been used in the early parts of the text are reused significantly. Just as the Holy Spirit "dominait" (hovered or towered over) the Virgin in the stained glass window, the neighbor La Simonne now stands on a chair to reach Félicité's window, "et de cette manière dominait le reposoir" (77) [and thus hovered over the altar]. Félicité, on her deathbed, breathes in the gray cloud of incense, and with her final breath sees "un perroquet gigantesque, planant au-dessus de sa tête" (78) [a gigantic parrot hovering overhead], just as, in her early years in the household, she had always imagined the stern memory of Mme 
Aubain's late husband "planant sur tout!" (47) [hovering over everything!]. The verbs "dominer" and "planer," used similarly in the story to convey the transcendent authoritarian values of a bourgeois and catholic society, draw attention to Félicité's own hierarchy of values. The parrot, now the icon not so much of the Spirit but of the beloved "bête" or animal, endowed with a language in which words of servility are a secret code of egalitarian tenderness, is the brilliantly colored gatekeeper to the "cieux entrouverts" (78) [opened heavens].

Bernardin de Saint-Pierre's novella La Chaumière indienne represents the encounter between a British ethnographer and a member of India's "untouchable" caste. In a brief 1966 article, English Showalter discusses the prominence of the expression "un coeur simple" in La Chaumière indienne. Bernardin had no particular ownership of the expression "a simple heart," Showalter notes, but the intentionality of Flaubert's reference is supported by the fact that Flaubert also used Bernardin's novel Paul et Virginie as an intertext in "Un Coeur simple" (Mme Aubain's children are named after Paul and Virginia, for one thing), as well as in other works $\left(5^{\circ}, 5^{2}\right)$. Showalter uses his reading of this intertextuality to weigh in on the irony/pathos debate. ${ }^{8}$ But he does not comment on the cosmopolitan nature of Bernardin's text, its critique of colonialism, its defense of multiculturalism, its argument for a decentering of knowledge, and its championing of abjection as an epistemological point of departure, all of which are highly pertinent to "Un Coeur simple."

La Chaumière indienne, published in 1790 at the opening of the French Revolution, begins with a critique of schools of thought and scholarly institutions. Bernardin claims that scholarly collectivities too often create obstacles to the acquisition and dissemination of knowledge through "leur jalousie et leurs préjugés" (6) [their jealousy and prejudices]. Much of this argument is articulated in the "Avant-propos" and its notes, rather than the main body of the novella. ${ }^{9}$ Bernardin elaborates the problem of the ethics of the exportation and importation of knowledge, as broached through the anecdote of a "compagnie de savans anglois" (3) [a company of British scholars], referred to elsewhere as the Royal Society, ${ }^{10}$ which had sought, some decades earlier, to "importer des lumières des pays étrangers en Angleterre" (5) [import the enlightenment of foreign countries to England]. Bernardin approves of this project, which presents an exception to the dominant movement of the exportation of European 
knowledge by explorers and colonists. Noting that in earlier eras, philosophy had come "des Indes en Europe" (6) [from India and Asia to Europe], he acknowledges that it may be the turn of Europeans to disseminate their cultures abroad, but also reminds readers of "les maux qu'y ont apportés les guerres et le commerce des Européens” (6) [the evils that Europeans' wars and commerce have brought (to Asia)]. In Bernardin's opinion, knowledge must not be excessively appropriated and controlled: "La vérité même est funeste aux hommes, quand elle devient le patrimoine d'une tribu" (18). [Truth itself can be a harmful force when it becomes the patrimony of one tribe.] He apparently means by this the European tribe, because the examples he gives are of the Inquisition and the "destruction des anciens Indiens de l'Amérique" (18) [the destruction of the former Indian populations of the Americas]. Bernardin seems to have in mind an abolition of privileges in the world of knowledge to accompany the recent abolition of feudal privileges in the French public domain; he argues that "[1]a science, cette mère commune de l'esprit humain, a aussi ses aristocraties; ce sont les academies" (22). [Science, mother to the human spirit, also has her aristocracies: the academies.]

This critique of elite institutions and of European intellectual patrimony as a potentially destructive influence when exported alongside imperialist commerce and military conflict favors those who are positioned outside of elite culture. (These outsiders include Bernardin himself, since he has had theories rejected by scientific academies-theories that unfortunately have not improved with time.) Within the space outside of academe, Bernardin introduces the history and politics of the genre of the story (the "conte"), and particularly the fable. Fables, he notes, are thought to have originated in "les pays despotiques de l'Orient" (7) [despotic countries of the East] because their truths are "veiled" in allegory. Bernardin doubts this explanation, hypothesizing that tyrants would be even more upset to see themselves emblematized in animal form than subject to overt political critique. This apparently frivolous point turns out to be quite important. Bernardin associates the origins of culture, particularly in Greece, with fables and metamorphosis:

Les peuples sauvages fondent leurs traditions sur des fables; il n'y a point de pays où elles aient été plus communes que dans la Grèce, où tous les objets de la nature, de la politique et de la religion, n'étoient que les résultats de quelques métamorphoses. Il y avoit peu de familles illustres qui n'ê̂t quelque animal au 
nombre de ses ancêtres, et qui ne comptât pas parmi ses cousins ou ses cousines, des taureaux, des cygnes, des rossignols, des touterelles, des corneilles ou des pies. (9-Io)

[The traditions of savage peoples are based on fables; this was especially the case in Greece, where the defining events and characters of nature, politics, and religion were merely the outcome of a few metamorphoses. There were few illustrious families who did not count some animal among their ancestors, and bulls, swans, nightingales, mourning doves, crows, or mockingbirds among their cousins.]

Bernardin links this belief in fables to proximity to nature (and thus freedom) and nature's laws (and thus the love of truth).

The language of the most civilized peoples is excessively dry and abstract in Bernardin's view: “[L]e langage des peuples civilisés ne peint rien, parce qu'il est plein d'idées vagues et d'abstractions, et celui des peuples simples et naturels est très-expressif, parce qu'il est rempli de similitudes et d'images" (12). [The language of civilized peoples is not descriptive at all, because it is filled with vague and abstract ideas, whereas that of simple and natural people is highly expressive, because it is filled with likenesses and images.]

Ignorance, Bernardin concludes, must not be confused with error (14). Ignorance shares “douces harmonies" (14) [sweet harmonies] with truth and represents not only the mind's repose but the beneficial forgetting of past, present, and future evils; it arises from nature. Error, on the other hand, is a man-made product: "Les tyrannies, l'esclavage, les guerres sont fondées sur des erreurs politiques, et même sacrées" (14) [Tyrannical regimes, slavery, and wars are based on political and even religious errors], he asserts. But fables are no more erroneous than ignorance: "Il faut bien prendre garde de confondre la fable avec l'erreur. La fable est le voile de la vérité, et l'erreur en est le phantôme" (15). [One must not confuse fables with error. Fables are the veil of truth, whereas error is the ghost of truth.]

In the main text of the story, we return to the "anecdote" about the British scholarly expedition in search of the world's truths. The main character, the most knowledgeable of these venerable savants, is sent to India, "berceau de tous les arts et de toutes les sciences (36) [cradle of all the arts and sciences]. In true fairy tale fashion, this scholar has already traveled much of the world and acquired trunks and boatloads of texts and 
answers to the three thousand and five hundred questions provided by the academy. But the answers to the questions have only multiplied the questions themselves, establishing chaotic multicultural relativism in the place of truth; the knowledge he has found has decentered knowledge itself.

Il s'ensuivoit que la société royale auroit trois cent cinquante mille difficultés à résoudre avant de pouvoir établir aucune vérité sur une base solide. Ainsi toute leur collection, loin de faire converger chaque proposition vers un centre commun, suivant les termes de leur instruction, les feroit au contraire diverger l'une de l'autre. (4I)

[The outcome was that the Royal Society would have one hundred and fifty thousand difficulties to resolve before it would be able to establish a single truth on a solid foundation. Thus, the entire collection process, far from making each proposition converge toward a common center, following the terms of the plan, would on the contrary make them diverge on separate paths.]

His final plan, however, is to question the Brahmin priest at the Jagannath Temple in Orissa, India. He is tempted to ask him about the rights of man, “dont il n'y a de code nulle part" (46) [a code of which does not exist anywhere], but this question is not in the Royal Society's book. When he arrives at the temple, he learns that he cannot speak to the high priest because he is impure. After a lengthy cleansing and purification process, he navigates endless levels of formalities and unnecessary translation. He is finally able to ask his question: Where should one seek truth? The priest answers that the truth is contained in sacred Sanskrit documents accessible only to the Brahmin descendants of Brahma.

When the exasperated doctor leaves the temple, a typhoon develops, and the only available shelter is the hut of a man who turns out to be of the caste now called "Dalit": an untouchable. The doctor's companions recoil, shouting, "A pariah!" and retreat to weather the typhoon in the open. The doctor is uninvested in the caste distinctions hastily explained by his companions and the pariah, and so he takes shelter with him and his family for the night. The rest of the narrative is devoted to their dialogue.

Virtually all of Bernardin's major political points thus far are applicable to Félicité: excluded from the tribal patrimony of truth, she learns from the book of nature. Her ignorance leads her to develop "fables" of meaning, characterized by strikingly nonabstract likenesses and 
metamorphoses. She invents a sacred lineage between the parrot/son/ lover and God, welcoming a bird into her "family." Her ignorance is arguably not the same thing as error, since through her fusion of Loulou and the Holy Spirit, she makes religion intelligible. She is not a pariah, but she is a peasant; Mme Aubain and others repeatedly show that they consider her to be in a fundamentally different category of existence. But once the pariah begins to speak, we find that Flaubert had attempted in Félicités characterization and speech something that Bernardin tried only in his abstract critiques of hierarchies: Félicité speaks from the borderlands between person and thing, in the discourse of her abjection. Bernardin's pariah, on the other hand, speaks like the visiting scholar. His social isolation is far more extreme, his child is "noir et poli comme l'ébene" (67) [black and shiny as ebony], but he explains to his guest that he has derived his principles "de la nature" (70) [from nature], and that he has been taught to read the book of nature by "le malheur" (70) [wretchedness]. This subaltern exemplifies the ways in which the subaltern does not speak, whereas in "Un Coeur simple," the other is represented as coming closer to finding words.

It is, however, the pariah who introduces the idea of "un coeur simple" (72), to express a state of being in which one does not live by deceptions. After he uses the expression twice in one passage, the doctor picks it up and runs with it, using it eight times in relatively quick succession. The final three usages of the expression are by the pariah, and lurking in Flaubert's authorship of "Un Coeur simple," we find this fictional pariah.

In response to the doctor's bafflement as to the extreme nature of his social abjection, the pariah explains the Hindu caste system in detail. He associates the learning of prejudices with mindless repetition, noting that "les hommes s'instruisent comme les perroquets" (80) [men learn like parrots]. In "Un Coeur simple," Loulou's endless repetition of either servile phrases or orders conveys this same idea of the parroting of social biases that are mechanically learned rather than reasoned out. But Flaubert's parrot has a creative and tender side to his copying, suggesting that the objects of social prejudices are those likely to have to do the most repeating in order to appease authority. They can, however, integrate creativity into this socially requisite mimeticism.

The pariah narrates a fascinating story of coming to terms with his isolation. Cities, as forbidden places filled with humans he must not touch, have become an object of desire for him. He goes to Delhi, where 
he is transfixed by the "congrégation d'hommes de tant d'états différens" (84) [congregation of men of so many different categories], especially in the arcades and the "vastes bazars ou marchés" (85) [vast bazaars or markets]. At times he is driven away by slaves securing their masters' environs from untouchables (except for one scene in which black slaves allow him to share their fire). He notices everywhere "des femmes qui se prostituaient publiquement pour avoir de quoi vivre" (86) [women who prostituted themselves publically in order to be able to eat]. He also observes eunuchs moving women on elephants from a burning harem. He reflects that morally many masters are themselves slaves (91).

Over time, he comes to urgently need a faithful friend who would be "inaccessible aux préjugés" (96) [untouched by prejudices]. He finds one "[qui] n'étoit pas dans mon espèce, mais dans celle des animaux" (96) [was not of my own species, but that of animals]: a dog. Unlike Félicité with her parrot, however, the pariah is not satisfied with the dog as a companion. His reasoning is that he needs a companion who would understand a life even more abject than a dog's. And who would that be? Woman.

Il me falloit un ami plus malheureux qu'un chien, qui connût tous les maux de la société humaine, et qui m'aidât à les supporter [.. .]. La providence combla mes désirs, en me donnant une bonne femme. (97)

[I needed a friend more wretched than a dog, who would know all the ills of human society and help me to bear them (. . .). Providence granted my wish by giving me a good woman.]

Even more astoundingly, the woman more wretched than a dog is not an untouchable, but a Brahmin.

He finds her in a cemetery, where he goes at night to eat from the food mourners leave in honor of the dead. She is visiting the grave containing the ashes of her mother, who was burned alive with the corpse of her father, "suivant l'usage de sa caste" (97) [following the customs of her caste]. As a pariah, he does not dare speak to her, and so "j'empruntai, pour me faire entendre, le langage des fleurs: j'ajoutai aux pavots des soucis" (99) [to make myself understood, I used the langage of flowers: I added marigolds to poppies]. ${ }^{11}$ Over a period of time, dialogue is established, and the pariah learns that she, too, faces immolation through the ritual of Sati, as her elderly husband is dying. They plan her escape and ultimately relocate to the remote cabin set among the roots and branches of a majestic tree, where they live happily as man and wife and have a 
child. Their extreme caste difference is annulled by her abjection as both a woman and a caste escapee, although their life together follows general conventions of gendered marital behavior.

In La Chaumière indienne as in "Un Coeur simple," the persons and things school is literal: education comes in the form of experiences of reification and autonomy. The education of Félicité and of the pariah is a pedagogy based on oppression, to play with the title of the work by Paolo Freire. But these two characters also provide a pedagogy of the oppressed by the oppressed to the increasingly socially diverse readership of modernity. At the same time, Flaubert and Bernardin de Saint-Pierre make social stories into stories about knowledge and signs. The challenge for a critical "persons and things school" inspired by the teaching and writing of Barbara Johnson is to think the social through knowledge and signs and to think knowledge and signs through the social. What is always on the curriculum for this "school" is the following question in relation to an infinite array of literary, theoretical, historical, and cultural texts: how do we know the difference between persons and things?

Deborah Jenson is Associate Professor of French at the University of Wisconsin-Madison. She is the author of Trauma and Its Representations: The Social Life of Mimesis in PostRevolutionary France (Johns Hopkins University Press, 2001), and editor and cotranslator of Hélène Cixous's “Coming to Writing” and Other Essays (Harvard University Press, 1992). She recently edited "The Haiti Issue: 1804 and Nineteenth-Century French Studies" of Yale French Studies (2005) and has prepared with Doris Kadish a translation and critical edition of Marceline Debordes-Valmore's colonial novella Sarah. She is completing a book manuscript on France and the Haitian Revolution.

Notes
$1 \quad$ Examples of texts taught in Johnson's "persons and things" courses are Keats's "Ode on a Grecian Urn" and the French woman novelist Rachilde's The Juggler, in which the heroine falls in love with an anthropomorphized urn.

2 There are so many excellent articles on "Un Coeur simple" that an accounting of critical literature would make an article in itself; I have had to choose here to limit myself almost exclusively to an analysis of the story itself in the framework of my thematic project.
3 Several extremely good translations of "Un Coeur simple" exist, notably the translation by Robert Baldick in Three Tales (New York: Penguin Classics, 1961); however, I have provided my own translations of citations in order to preserve the clearest ties between my interpretations and the quotes that illustrate them. Here and throughout the article, translations are mine unless otherwise noted.

4. In another passage, Félicité associates together "l'Amérique, les Colonies, les Iles" (59) [America, the Colonies, the Islands] as one perilously distant abstraction. 
5 On the issue of the status of slaves brought to France with their owners, see Peabody.

6 Although Flaubert insists on Loulou's limited verbal repertory, we are also given the detail that the parrot imitates not only Félicité's reverential speech, but Mme Aubain's orders: "Félicité! la porte! la porte!” (70) [Félicité! The door! Get the door!].

$7 \quad$ Folk art and religious engravings were published in the town of Epinal in popular series like the Imagerie d'Epinal in the nineteenth century. This detail denotes Félicité's popular visual "literacy"; she is crossreferencing the stained glass window image with religious images often sold in collections by peddlers. See Jean Mistler, François Blaudez, and André Jacquemain, Epinal et l'imagerie populaire (Paris: Hachette, 1961).

8 Showalter argues that the "indifference of the universe" manifested in relation to Flaubert's main character, Félicité, presents an ironic contrast to "the worthiness of man" (55) highlighted by Bernardin's main character. Nevertheless, Showalter concludes, this is "an irony hardly distinguishable from compassion” (55).

$9 \quad$ There is a publically available online edition of this text by Gallica.fr, but it is important to note that it features the "Avant-propos" as a separate document. The online edition by Biblisem does not include this essential part of the text at all.

10 This was probably the Royal Society of London for the Improvement of Natural Knowledge.

11 Not coincidentally, this same device, of courting an inaccessible woman by strewing marigolds or "soucis," a term that also means "worry" or "care," is used by the slave Bug-Jargal in Victor Hugo's 1826 novel of that name.
Works Cited

Bernardin de Saint-Pierre, J. B. H. La Chaumière indienne, et le café de Surate. London: n.p. 1792. Available online through Eighteenth Century Collections Online.

Flaubert, Gustave. “Un Coeur simple.” Trois contes. Paris: GF-Flammarion, 1986. 43-78.

Freire, Paolo. Pedagogy of the Oppressed. Trans. Myra Bergman Ramos. New York: Continuum, 2000 .

“Jacquerie.” http://fr.wikipedia.org/wiki/Jacquerie (accessed 7 August 20o6).

Jenson, Deborah. "Fetishism: Thinking with Things in Flaubert's 'Un Coeur simple." Trauma and Its Representations: The Social Life of Mimesis in Post-Revolutionary France. Baltimore: Johns Hopkins up, 2001.

Johnson, Barbara. "Ode on a Public Thing." Field Work: Sites in Literary and Cultural Studies. Ed. Marjorie Garber, Paul B. Franklin, and Rebecca L. Walkowitz. New York: Routledge, 1996.

Mistler, Jean, François Blaudez, and André Jacquemain. Epinal et l'imagerie populaire. Paris: Hachette, 1961.

Peabody, Sue. There Are No Slaves in France: The Political Culture of Race and Slavery in the Ancien Regime. Oxford: Oxford UP, 1996. 
Pontes, Eunice. "The Distinction between Persons and Things in Portuguese Pronouns." Cadernos de linguistica y teoria da literatura 2.3 (Dec. 1980): 97-104.

Pottage, Alain, et al. Law, Anthopology, and the Constitution of the Social: Making Persons and Things. New York: Cambridge uP, 2004.

Schor, Naomi. "Idealism." A New History of French Literature. Ed. Denis Hollier et al. Cambridge, MA: Harvard UP, 1989. 769-74.

Showalter, English, Jr. “'Un Coeur simple’ as an Ironic Reply to Bernardin de Saint-Pierre.” The French Review 4,0.1 (1966): 47-55. 